\title{
Rule of Law and Institutional Legitimacy: Challenges of Transition, Challenges of Europe
}

Prof. dr. Nina Peršak*

Ghent University, Belgium

nina.persak@ugent.be

\begin{abstract}
Recent European events have revealed that some EU Member States, including some South Eastern European (SEE) States, still struggle with the rule of law. While certain rule of law challenges may be due to past legacies and insufficient (or insufficiently successful) transitions, others may be the result of the transition itself and of contemporary socio-economic problems that are experienced across Europe. This article will address the state of the rule of law in SEE, reflecting first on some pre-, mid-, and post-transition problems relevant for the rule of law in these countries. Next, it will address the legal and socio-psychological impact of the challenges posed by the mentioned problems, connecting the (mis)trust that can be observed on several levels (internally and externally) with the rule of law, thus demonstrating that mistrust as such has social as well as legal consequences. If trust (e.g. in the effectiveness of the rule of law safeguards or in those who are entrusted with safeguarding it) is lacking, this represents a problem not only for the Member State (e.g. for the functioning and perceived legitimacy of its judicial system) in question, but also for the EU (e.g. for the judicial cooperation in criminal matters). Lastly, the article will examine the EU's perspective on rule of law, drawing on the recent EU Framework to Strengthen the Rule of Law, which aims to ensure an effective and coherent protection of the rule of law in all Member States, as well as on some other EU documents that may, in our view, help address the current challenges in European rule of law.
\end{abstract}

Keywords: transition, rule of law, legitimacy, Europe, EU, challenges, crisis

\footnotetext{
* Prof. dr. Nina Peršak, LL.M. (Cambridge), Ph.D. (Ljubljana), M.Phil. in social and developmental psychology (Cambridge), professor of criminology and sociology of law, Faculty of Law, Ghent University, Belgium.
} 


\section{Introduction}

Rule of law is a complex, "essentially contested" (Waldron 2002: 173) concept. Although widely recognised as one of the most important political ideals today (Tamanaha 2004; Waldron 2008), "the benchmark of political legitimacy" (Waldron 2008: 1) that societies of today should maintain or aspire towards, it has also become a sort of all-encompassing catchphrase used by politicians, NGOs, media, and the regular John Doe on the street, and is often invoked in order to voice disappointment of some sort with the existing state of affairs. Despite its "unmatched rhetorical power" (Taylor Hamara 2013: 11) that impresses, persuades, and legitimates, the concept remains rather vague and is used differently not only within the ordinary, everyday discourse, but also among academics. While some see it as a formal concept (rule of law, not of men), others see it predominantly as a substantive, moral concept (that says something about the content or quality of law, for example - see Finnis 1980), while others still take it as a combination of both dimensions (Flores and Himma 2013). ${ }^{1}$ While the lack of conceptual clarity is definitely something that we should aspire to correct, or at last reduce, it does not paralyse us in pursuing the task of assessing how this concept - vague or vaguely used as it may be - is being applied (and seen as being applied) in Europe. When the functioning of the rule of law is, for example, being assessed in a certain South Eastern European (SEE) country by, for instance, EU institutions, the latter must operate with certain assumptions, normative concepts, procedural and moral standards, or normative expectations, which the state being assessed is supposed to fulfil. When noticing that a certain Member State (that is, its state institutions) attempts to weaken the rule of law safeguards and thereby falls short of this [371] political ideal, the EU attempts to intervene, not at all being held back by the lack of clear definition or lack of consensus on the precise meaning of the rule of law in some EU Member State.

Recent EU events have indeed revealed that some EU Member States, including some SEE States, still struggle with the rule of law. Looking at challenges concerning the rule of law in SEE, one common-sense conclusion would be that challenges may occur because of past legacies

\footnotetext{
1 One of the more recent overviews of the concept claims that scholarly conceptualisation of rule of law is not much better than those of political leaders. The authors Nardulli, Payton and Bajialieh describe the situation in the following way: "In some contemporary scholarship, a Hobbesian perspective is taken and the rule of law is seen as being synonymous with societal stability (Hirshleifer 1995; Dixit 2004; Belton 2005). Political conceptions focus on governmental constraint, namely, a government that obeys its own rules and is subordinate to an independent judiciary (Buchanan and Tullock 1962; Hayek 1973, 1979; Dicey 1915/1982; Olson 1993; Weingast 1995, 1997). Classical economic conceptualizations focus on the importance of property rights and contract enforcement (North and Thomas 1970; North 1990); others emphasize governmental transparency, efficiency, and corruption (Knack and Keefer 1995; Mauro 1995; Keefer 2004). Yet another conceptualization treats the rule of law as being synonymous with freedom/ human rights (Sen 1999)" (Nardulli, Peyton, and Bajjalieh 2013: 141).
} 
and due to the countries' insufficient (or insufficiently successful) transition into fully democratic states. Yet, the story does not stop there. Other rule of law problems (such as the phenomenon known as 'state capture') may be the result of the very transition into democratic, capitalist societies. However, there are also factors that may be less connected to the specifics of the past regimes and transitions, and are concerned more with the contemporary socioeconomic problems that are experienced across Europe, which make us question the social, distributive justice, the dominant economic model, and those who govern.

This article will address the general state of the rule of law in SEE, reflecting on the countries that underwent transition (in particular Slovenia), unpacking first some pre-, mid-, and post-transition problems related to the rule of law in these countries. Next, it will address the legal and social, or socio-psychological, impact of the challenges posed by the mentioned problems, connecting (mis)trust (which can be observed on several levels) to the rule of law. It will be demonstrated as well that such mistrust has not only social but also legal consequences. Trust (or lack thereof) affects the perception of an authority's legitimacy and consequently people's cooperation and compliance with the law, thus having a significant impact on the "effective rule of law" (Tyler 2003). Accordingly, if trust (in the effectiveness of the rule of law safeguards or in those who are entrusted with safeguarding it) is lacking, this presents a problem for the Member State in question, for instance for the functioning of its judicial system. The lack of trust, however, also has an impact on the EU, considering the fact that mutual trust is, for example, crucial for the functioning of instruments of mutual recognition, which are progressively being used in the judicial cooperation in criminal matters. Following this discussion, the article will finally examine the particular EU perspective on rule of law, drawing on the recent EU Framework to Strengthen the Rule of Law (which aims to ensure an effective and coherent protection of the rule of law in all Member States by providing a framework for the resolution of situations where there is a systemic threat to the rule of law), as well as on some other EU documents (such as the EU Justice Scoreboard, the EU Justice [372] Agenda, etc.) that may, in our view, help address the current European rule-of-law challenges.

\section{Pre-, mid-, and post-transition problems related to the Rule of Law in SEE}

When it comes to SEE Member States, the difference or challenges in the functioning of the rule of law is more or less assumed to arise (or to have arisen) from the different economic and political system that prevailed in the not-so-distant a past, as well as in the changes that these countries needed to adopt quickly on the way to their final goal - which again is more or less assumed to be the Western European ideal. Transition, it is often claimed, has either not been 
complete or has not been sufficiently successful, thus accounting for these countries' problems with the rule of law.

Before addressing these issues, it is first useful to remind ourselves that although 'transition' is more commonly used to describe the period following the 'turn' from the socialist, communist, authoritarian era to the democratic, post-communist states, the singular form is somewhat misleading. What the SEE countries experienced would be better termed 'transitions', since there were several of them, distinguished by kind (political, economic, cultural, etc.) as well as by place and time. ${ }^{2}$ With respect to time, we can talk of at least three transitions to date: the one in the early 90s (changing the political, legal, and economic system), the one of the mid-1990s (2004 for Slovenia, around joining the EU), and the one we are still more or less experiencing at the moment, that is, the transition instigated by the economic crisis, or 'crisis transition'.

What ensued from the 90s transition was the changing of laws - with some changing more quickly than others. In addition to criminal law, laws enabling privatisation and denationalisation, including changes to constitutional law, crucially contributed to the state of affairs that followed. On the one hand, this led to good consequences in the sense of repairing some past injustices and leading the countries closer to EU accession through the legal changes adopted. On the other hand, though, some things deteriorated, as swift privatisation [373] across the board caused many new injustices and a reduction of social security. Comparing several post-communist countries, Gosztonyi (2005) noted that the social security has deteriorated in each and every country, as previously free-of-charge services became payable and benefits were reduced or became more difficult to obtain. In the comparative survey, carried out in the Czech Republic, the former German Democratic Republic, Poland, Slovakia, and Hungary, the loss of safety was reported as the most shocking experience. The ratio of those who in the mid-1990s believed that their situation was worse than it had been before the transition has grown everywhere. In Hungary, for example, $61 \%$ of the population felt safe before 1989 and only 29\% after 1989 (Gosztonyi 2005). A similar effect followed the mid1990s transition: a recent overview of the economic effects of the EU's Eastern enlargement on the new Member States further reveals that while the economic growth, expansion of trade, and increase in foreign direct investment were obvious gains for the eastern EU countries, it also involved costs, as the size of domestic and foreign debts have greatly increased to finance their successes (Jovanović and Damnjanović 2013).

\footnotetext{
2 "In this regard, transition does not merely belong to the (semi)past of societies, which have escaped the clench of 'communist' or bureaucratic-authoritarian (or 'totalitarian', 'undemocratic' or 'unfree') regimes, but is also (or even predominantly) our everyday reality (which will in all likelihood continue to occupy a significant proportion of our not likely very bright future)" (Kanduč 2013: 618-619).
} 
Among the 'teething problems' experienced by the new democracies - quite possibly because of their cognitive blindness linked to the happy or 'honeymoon' period that followed the transition - there were various harmful practices, for example 'wild privatisation', which was in Slovenia later dubbed 'the theft of the century'. Observing the problems in various postsocialist countries after the shift led Gosztonyi (2005) to describe crime as one of the 'costs of transition'. According to Dobovšek (2012: 168), the transition to a market economy also greatly influenced the spread of corruption, with ethics and moral values being "pushed aside in the frenzied race for greater profit by individuals and indeed the whole societies of these countries".

Economic criminals that are being prosecuted today were at the time 'great businessmen', people who had 'made it'. They were featured in the media as successful, smart people to be admired. The practices of many of these 'admirable' people initially focused on wealth accumulation, then transformed into power, and later into a phenomenon that is often described today by the notion of 'state capture', where the economic elite (sometimes called tycoons, barons, etc.) de facto usurps the state by forming powerful networks that influence the political elite, who decides in the name of the State but in favour of their own interests and private agendas. State-capturing corruptive activities that affect the formulation of laws range from buying votes in the parliament to offering bribes to government officials in order to influence government regulations, from bribing judges to affect judicial decisions to illegal funding of political parties (Dobovšek 2012). Corruptive practices can distort the rule of law, while [374] a weak judiciary often fails to seize the moment and reinstate the rule of law though the timely prosecution and punishment of the crimes of the powerful. Even when the judiciary is not a weak spot, however, the problem is that state capture is difficult to break down into individual offences without losing sight of the big picture. Furthermore, what makes it particularly difficult for prosecution in transitional societies is that in these countries "distinctions between private and public actions may be unclear, which makes it difficult to determine who is taking over whom" (Dobovšek 2012: 171).

To a large extent, this is still an on-going state of affairs in many post-socialist or postcommunist European countries. ${ }^{3}$ Dissatisfaction with how things were handled during the transition(s), resulting in the impoverishment of whole segments of the population and whole regions that depended on a certain industry or factory - and aided, furthermore, by today's economic crisis - has made many people voice their concern about capitalism and neo-liberal political economy, which the USA and the EU are seen as propagating. The cynicism towards the economy and those leading it, coupled with the mistrust towards the state (or those who were supposed to keep an eye (or lid) on the more carnivorous aspects of capitalism) has led some to

\footnotetext{
${ }^{3}$ For an illuminating description of the merging of the former party elite, secret services, and the new political and business elites at the start of the democratic transition in Bulgaria, see Slavov (2011).
} 
start advocating the idea of reviving socialism - or more concretely, 'democratic socialism'. Although many critics (and those who have lived in socialist times) find it idealistic or utopian or plain ridiculous, the idea is attractive to many young people who live in a state of precariat, having no steady employment and no union representative, moving in and out of the workforce on various short-term work contracts (that offer much less social security) and remaining largely invisible, despite their rising numbers. The recent (July 2014) parliamentary elections in Slovenia have (perhaps for this very reason) seen an unexpected rise of a newly established party, called United Left (Združena levica), that not only entered the Parliament with the fourth largest number of votes but also took many of the votes from the parties who have been 'on the scene' since Slovenia's independence in 1991 (one of them being the party of Social Democrats).4 This party has been named the biggest surprise of these elections. Its success was [375] explained also by pointing to its 27-year-old political leader, an ardent proponent of 'democratic socialism', who was widely recognised as the representative of the precarious workforce (many of whom had been thus far too disillusioned to even vote) and held his ground well in the pre-election debates.

\section{Rule of law issues in SEE: the legal impact of transitional challenges}

\section{Impact at the legislative level}

The general role of law is to balance diverse values through norms. Durkheim, for example, considered law to be the most important observable manifestation of the collective consciousness and its transformation (Deflem 2008). Law contains the fundamental values of society (thereby normatively regulating it) and, moreover, censures (allocates blame, conveys moral reprobation) the violations of such norms (values) through punishment. In the area of legislation, transitional changes towards the rule of law were in many European transitional countries mostly reflected in the area of constitutional law and criminal law, that is, through the fundamental regulatory systems of society.

Criminalisation, and criminal law in general, is from the individual's standpoint one of the most intrusive forms of social control and repressive acts of state power, for it not only restricts one's freedom of action but also punishes infringements, often depriving the individual of his or her liberty (imprisonment) and significantly (and detrimentally) impacting the

\footnotetext{
4 Some claim that this is where the parties of 'the new left', such as United Left in Slovenia, Greek Syriza, German Die Linke, or French Le parti de gauche, get most votes from - that is, taking them from the old, already well-established social democratic parties in Europe, who have "ideologically moved more towards the liberal centre and now wonder why they are losing votes of the left" (Belovič 2014: 3).
} 
fundamental rights of the individual (Peršak 2007; Erbežnik 2014). During transition time, criminal law held particular importance for social justice. As Goodall, Malloch, and Munro (2012: xii) observe: "Emerging concepts of criminalisation and decriminalisation are not only the results of changing concepts of justice during transition and post-transition: they change social understandings of justice itself." This can be clearly seen, for instance, in the case of Slovenia. After Slovenia became an independent country, one of the first changes in the criminal law was to remove the notion of 'social danger', which was at the time one of the constitutive elements of the definition of 'criminal offence'. Social danger smacked too much of the past regime, where it was commonly abused, being used, for instance, to criminalise 'public enemies' as it was vague enough to allow any sort of anti-state or anti-regime conduct (mostly exercises of the freedom of speech) to fit the mould of 'criminal offence'. Transitional criminal law was thus also used as a way of dealing with the past. Transitional justice as the coming-to-terms with the communist past can also [376] (at least in part) 5 be reflected through the transitions or modifications of the country's (criminal) law, which is always vested with people's perceptions and notions of justice (Peršak 2012), and this is what to some extent happened in Slovenia through its black-letter law. While Slovenia may have moved "beyond the crimes of the past without the benefit of 'truth and reconciliation'" (Kotar 2009: 201, 216), a certain transitional justice has manifested itself through the criminalisation as "justice on the books".

The changes in the rule of law were, however, primarily reflected on the constitutional level. The new Constitution of the Republic of Slovenia marked the independence of Slovenia (after the dissolution of Yugoslavia) ${ }^{6}$ and set the grounds and principles for the functioning of the new liberal democratic state. Before the transition, rule of law in its full meaning did not exist (Bučar 2004). The Slovenian Constitution, adopted on 23 December 1991, therefore laid the foundations of state power and of the position of individuals in the Republic of Slovenia: it clearly stipulated that Slovenia is a "state governed by the rule of law and a social state" (Art. 2) and that the power is executed by people, according to the principle of the separation of powers (Art. 3); it listed basic human rights and fundamental liberties (including the principle of legality and legal guarantees in criminal proceedings); and it discussed economic and social relations, while also including a chapter on state organization (which includes an article on judicial independence), on self-government, public finance, constitutionality and legality, on the

\footnotetext{
5 This does not mean, however, that those who wronged others in the past should escape political or legal accountability.

${ }^{6}$ Slovenia gained independence on 25 June 1991 with the adoption of the Basic Constitutional Charter on the Sovereignty and Independence of the Republic of Slovenia by the Assembly of the Republic of Slovenia. On 23 December 1991 the Assembly also adopted the Constitution of the Republic of Slovenia, which has been later amended by seven constitutional acts. The Slovenian constitutional system is also founded on two Constitutional acts: the Constitutional Act Implementing the Basic Constitutional Charter on the Sovereignty and Independence of the Republic of Slovenia, and the Constitutional Act Implementing the Constitution of the Republic of Slovenia. See: https://www.dz-rs.si/wps/portal/en/Home/PoliticniSistem/UstavaRepublikeSlovenije.
} 
Constitutional court and others. The Constitution therefore clearly stated its adherence and dedication to the rule of law.

To conclude, it can be seen that transition processes in the 90 s had a special relationship with the rule of law. The discrediting of socialism and the end of the Cold War have been highlighted as important factors that "stimulated the 'rule of law revival' that began in the 1990s" (Nardulli, Peyton and Bajjalieh 2013: 140). The political reforms that ensued were thus aimed at enhancing the [377] accountability of leaders through democratic reforms and strengthening civil societies. This, however, could not have been done without legal reforms, as "without a credible commitment to accept constraints on discretion and comply with wellknown rules of the game, neither free enterprise nor democracy would thrive" (ibid.).

\section{Impact at the level of the judiciary}

Perhaps even more crucial for the health of the rule of law in a country is what happens on the judicial level. The government may act in a way that jeopardises the rule of law, but as long as the courts correct this by, for example, annulling the government's decision or some problematic legislation, the rule of law in the state is assumed to function - that is, the state is considered to be abiding by the requirements of the rule of law. The Roma crisis in France can be taken as a case in point. In the summer of 2010, the French government initiated a programme to repatriate thousands of Romanian and Bulgarian Roma people, demolishing their camps, putting them on planes, and sending them back to their countries of origin. The European Commission saw this as a "rule of law crisis" (Reding 2013) and intervened by issuing a public statement in which the Commission made it clear that it considered that the rights of people belonging to an important minority were in jeopardy, particularly due to the evidence of a discriminatory application of EU rules on free movement and its provisions on when an EU citizen can be deported back to the Member State of his or her origin. Owing to the EC intervention, the free movement legislation in France and in other Member States has been changed and aligned with EU law to provide all the required procedural guarantees. Moreover, all EU institutions and Member States have agreed to a European Framework for national Roma integration strategies (Reding 2013). In March 2011, the French Constitutional Council declared unconstitutional and annulled several articles of the law that had served as a legal basis for the expulsion of Roma people.

In many SEE countries, the transitional period saw changes being brought about, for example, in the way judges were being nominated and their independence maintained. Modern provisions regarding judicial independence have also been inserted into their constitutions, although time has shown that some pre-democratic habits can be hard to break. In Romania, for 
example, the government and parliament in the summer of 2012 adopted a series of extraordinary measures in an attempt to oust the President of the Republic. Emergency decrees and laws were passed, aimed to reduce democratic checks and balances by imposing sudden limits to the powers of the [378] Constitutional Court. Moreover, judges and prosecutors were being subjected to pressures and intimidation from political forces. All this has raised concerns with regard to the country's respect for the rule of law, for democratic checks and balances, and judicial independence (Reding 2012). In its report, the European Commission (2012a) stated its concern with respect to the limitation of competences of the Constitutional Court relating to parliamentary decisions, and urged the Romanian authorities to restore these competences. The pressure exercised by members of the Romanian Government and senior politicians on the Constitutional Court were furthermore declared "unacceptable interventions against an independent judicial institution" (European Commission 2012a: 5). The intervention of the Commission helped to restore the authority of the constitutional court and bring the constitutional conflict to an end.

In Hungary, on the other hand, the Commission had to intervene when powers (without appropriate safeguards) had been granted to the President of the National Judicial Office (i.e. a non-judicial authority) to designate a court in a given case, as well as regarding the possibility to transfer judges without their consent. In April 2012, the Commission referred Hungary to the Court of Justice of the European Union for two infringement cases, one of them being the sudden reduction of the retirement age for judges, prosecutors, and notaries from seventy to sixty-two years. In its ruling of 6 November 2012, the Court confirmed the Commission's legal stance and found the Hungarian forced early retirement of judges, which would affect $10 \%$ of the Hungarian judiciary, incompatible with EU law (European Commission 2012b; Reding 2013).

\section{Socio-psychological impact of the transitional challenges: (mis)trust and its consequences}

Democratisation in the 90 s provided a basis for the building of trust in state institutions. Institutional trust had been significantly reduced under the Communist regime (Letki and Evans 2005), and hence the new democratic governments have from the outset been faced with a citizenry characterised by low levels of trust (Rose-Ackerman 2001). Some have noted that distrust and cynicism could have been labelled as "the predictable legacy of Communist rule", as well as quite a natural consequence of living under Communist regimes, since even though they varied in degree of totalitarianism, all regimes were "inclined to subjugate individual interests to those of [379] the Communist Party" (Mishler and Rose 1997: 419-420). This is said to have 
resulted in alienation from state institutions and a lingering distrust toward both political and civil institutions (ibid.).

During the pre-accession period, there was a strong group of Slovenian intellectuals advocating a resistance towards joining the EU. They believed that things would become more expensive, and that they would somehow lose out and end up worse off. Still, the large majority welcomed accession, which brought with it several expectations and consequently disappointments, as all expectations were not met and some processes, such as privatisation, caused certain social discontent (Peršak 2011). After accession, however, the general opinion improved in line with the rising standard of living. Recently, though, the general opinion has changed once again. Although Slovenes seem to trust EU institutions more than their own, this trust is not high. ${ }^{7}$ It does not help that several Slovenian governments tended to blame 'Brussels' for any and every unpopular measure they had to take, while simultaneously 'nationalising' the more popular measures (which equally originated from the EU institutions). 'Brussels' has thus become a Leviathan or a 'folk devil' to serve political goals, playing the role of a scapegoat for all things unpopular (such as demanding that Slovenians work more, pay for this or that, prove that they spent EU money correctly, and supervising Slovenians' every move and punishing them if they have not followed all the EU's 'bureaucratic' rules).

What lies behind it? And what enables this political construction of Brussels as the abstract 'Other' that apparently 'dictates' to poor national governments what they must do? The underlying reasons may be located in the general public alienation that can be sensed in many of the post-2004 Member States - that is, in their lack of a sense of belonging and essentially their lack of trust.

Trust

Trust is important for various reasons. It is, for instance, essential for 'perceived legitimacy', which affects compliance and cooperation (Tyler 2009, 2012). In our context, it may be important also for democratic consolidation. There are three levels of trust that are relevant for our purposes, which will be addressed in turn: (a) public trust toward national political institutions, (b) trust towards the EU, and (c) inter-Member State trust (mutual trust).

a) While distrust seems to be currently endemic, post-socialist states seem to suffer the most from it. Looking at the recent Eurobarometer findings [380] measuring the trust in courts (see Eurobarometer 2013), a clear gap can be observed between public trust in some EU states (particularly Nordic states) and post-socialist or post-communist EU states. The socialist or

\footnotetext{
7 In June 2014, only $6 \%$ of Slovenian respondents trusted the national parliament, $8 \%$ trusted the government, and $37 \%$ of those asked replied that they trust the EU (Eurobarometer 2014).
} 
communist roots of distrust have partly to do with the harms of state socialism (Ward, in Hillyard et al. 2005) and the general fear of people living under such regimes that the state might be listening, and might find them to be a public enemy and convict them of crime against the state or the People.

The reduced trust and consequent 'legitimacy crisis' of today has infested several institutions - from police and governments to parliaments and courts. While governments often come under attack during economically bad times, courts come under fire if they are perceived as failing to deliver justice and correct wrongs. During the socio-economic post-Cold War transition period, judicial legitimacy had a lot to do with the correcting of wrongs (be it through lustration or repealing totalitarian laws that violated human rights). Today, on the other hand, the sore spot seems to be particularly centred in the area of financial and economic crime, for example in cases of 'corruption' and 'corruptive conduct' that are highlighted in the media, critically examined by the relevant authorities, and even prosecuted and brought to court. In Slovenia, such cases seem to act at the moment as a catalyst for morality and the collective assessment of ethical conduct and values (of the system and individuals), a sort of societal cleansing of the anything-goes mentality that turned a blind eye to many social harms of the corporate crime in the 90 s (i.e. the first decade of transition). These days, moreover, what to define as corruption or 'corruptive practice' has become a type of ethics in itself. No one including (or especially) high-profile CEOs and directors that have been found to be corrupt seems to feel responsible for their actions, nor do they seem to understand what they have done wrong. Such people tend to stay in their positions in the public office as long as possible, often until the finality of the judgment. Criminal conviction, then, acts as a conveyor of morality: it is only upon the conviction that people learn what is wrong and consequently what is right (as a negation of wrong). In such an ethically challenged society, criminal law is definitely a centrepiece of Rechtsstaat and of societal development.

b) Moving away from the issues or problems of intra-state trust and looking at the trust of EU Member States towards the EU (i.e. EU institutions and the idea of the EU), the challenges that arise have a lot to do with the idea of belonging (and wishing to belong) or with emotional attachment. Stoeckel (2012) has empirically shown, for example, that trust in EU institutions and attachment to Europe decrease indifference and ambivalence about the EU. The idea of belonging includes preferring to see similarities (glass half full) [381] rather than differences (half empty) between oneself and the major group. In the context of the EU, this would mean striving for Europeanness, that is, seeing and representing oneself as (also) European. However, considering that the support for future EU enlargement has been dropping in almost all Member States since the early 2000s, including in some of those which are official candidates for membership (Toshkov, Kortenska, Dimitrova and Fagan 2014), and considering that national 
political parties with Eurosceptic sentiments having been reaping electoral gains (Harteveld, van der Meer and De Vries 2013), this may present quite a task.

Some research shows that European citizens trust EU institutions more than they do their own national institutions (Eurobarometer 2014), while others note that the EU is "facing its worst crisis of confidence" (Jovanović 2013). ${ }^{8}$ National governments add to this by using the image of a distant, cold 'Brussels' as a scapegoat whenever they have to implement unpopular policies. The fact that many people seem to fall for this, however, indicates that they do not see Europe as 'us' and that it is their lack of belonging to Europe (EU) that facilitates these stories. This was also recently highlighted by the EU Commissioner Bulc (during her hearing as a candidate for a commissioner for transport), who said that EU citizens have to realise that they are spending their own money and that therefore having strict supervision over the spending of EU money is in their best interest (rather than something 'Eurocrats' like to do for fun). Moreover, through resolutions and (the transposition of) directives, the EU law becomes effectively national law, which can (and should) lead to further normative integration of the 'received' EU norms, seeing them effectively as 'ours'. ${ }^{9}$ The extent of the difference may therefore be in a state of flux, constantly [382] reducing with the passing years that bring with them more and more EU laws penetrating into 'our' national legislation.

Still, the building of trust in the EU depends also on the EU itself (and its institutions). One important element in generating trust (and institutional legitimacy) is procedural justice, or fairness of treatment on the part of the power-holder (Tyler 2003, 2009, 2012). Pre-2004accession, many new Member States were carefully watching what the EU does. What they could observe, inter alia, were some double standards being applied with respect to the conditions demanded for joining the EU. For the ten new Member States acceding in 2004, conditions were stricter than for many of the 'old' Member States. Such differential treatment was not appreciated, however, and it could have hindered subsequent cooperation, as double standards are not a sign of respect or respectful treatment. The theory of procedural justice clearly establishes a link between the quality of one's treatment and their attribution of trust

\footnotetext{
8 "The current crisis is shaking the foundations of the EU. The member countries can agree on almost nothing. The awarding to the EU of the Nobel Prize for peace in 2012 was one of the first pieces of positive news regarding the EU in years. [...] The core EU countries such as France and Germany are drifting apart (this is one of the most serious problems), while others such as Britain are disengaging from the EU project. Countries in the EU move at diverse speeds (Eurozone and others), while some (Britain) are moving in a different direction to the rest of the EU" (Jovanović 2013: 2).

${ }^{9}$ This may not, however, be an easy task in a diverse Europe. Mediating among the plurality of ethical value systems is thus, according to Habermas, the primary task of modern law (Deflem 2008). The EU law is 'by default' such a modern law, and this challenge of overcoming or mediating among the plurality is particularly acute in its case. The mediating and integrative function of law becomes more needed when the degree of cultural diversity in a society rises, which is why the pluralist, multicultural societies of today present many challenges even to the national law, let alone to the supranational law.
} 
and consequent perceived legitimacy to the authority that treats them in a certain way. ${ }^{10}$ The EU is such an authority here and coming down hard on new Member States while allowing all sorts of exceptions for the older Member States cannot help the trust-fuelled cooperation with the EU. In other words, the EU has to live up to its own standards first, before measuring others against them - or, as Wolff (2013: 119) puts it, in order "to be a credible rule of law promoter abroad, rule of law standards at home need to match what the EU preaches abroad".11

c) Considering that trust is context- and place-specific (Crawford 2000), attention should also be paid to background, historical, and cultural nuances, which have to be appreciated, for example, for the EU to merit legitimacy and generate compliance, mutual respect or mutual trust. Inter-state trust or 'mutual trust' - i.e. the idea of trust existing between Member States that lies behind many mutual recognition instruments in the area of judicial cooperation in criminal matters - similarly has to acknowledge differences. Overlooking the [383] differences in the national constitutional identity of Member States, differences between their national systems and their perception of justice that leads to "an uncritical application of mutual recognition based on 'commanded' mutual trust" (Erbežnik 2014), may thus run the risk of unnecessarily creating resistance against and mistrust towards cooperation in criminal matters in the EU.

Acknowledging diversity, at least in law, does not seem to present a problem for the EU. According to Art. 4(2) of the Treaty on European Union (hereafter: TEU), for example, the EU must respect 'national identities' (similarly stated in Art. 82(2) of the Treaty on the functioning of the European Union (TFEU), which refers to judicial cooperation in criminal matters): the EU, it declares, must take different national legal traditions into account. However, even though the EU values diversity, it is perhaps understandable that it might also be inclined (particularly in its policy documents and laws) to downplay national differences, especially when they may lead to stereotyping, discrimination, or measures threatening the freedom of movement within the EU. Furthermore, the idea of the European Union itself presupposes that certain commonalities exist (or should eventually exist) between all states that join this union. Within the EU or western liberal democratic societies, commonality can be drawn from the shared Enlightenment heritage, reflected in the commonly agreed upon criminal law principles. Thus, despite the cultural variability within the EU, there are several fundamental values and common

\footnotetext{
${ }^{10}$ A similar situation has been observed in a research study on Ukraine and its rule of law. Burlyuk (2013: 208) writes how in Ukraine a combination of low legal culture and "total lack of trust in the system" is reflected in people's general unwillingness to collaborate with the law enforcement institutions, which is manifested, for example, in the low numbers of people who are willing to report a crime.

11 This is particularly relevant for those who tend to trust an authority based on its performance (including procedural justice). Some research, however, suggests that people's trust in the EU is rather an extrapolation of their trust in their national authorities. According to Harteveld et al. (2013), a citizen's 'national' trust was a stronger predictor of his or her trust in the EU than trust based on perceived performance of the EU and trust based on identity or emotional attachment to the EU.
} 
grounds (referred to in many EU legislative documents) on which the EU criminal law can be built in a consistent way. ${ }^{12}$

However, while diversity is a fact and needs to be acknowledged and taken into account, it should also not be overestimated or 'left unquestioned' (Goodall, Malloch and Munro 2012). In the area of criminal law and criminalisation, for example, much of a country's criminal law regulation does not involve the country's specific historical, cultural, and ethical basis (Elholm 2014). If it is mainly criminalisations mala prohibita, as suggested by Nuotio (2014), that are [384] specifically connected to the particular conception of the good in a society, it is therefore likely that more 'core criminalisations' - i.e. more basic harms or crimes (which tend to comprise the majority of crimes described in the Criminal Codes, considering mala prohibita are still considered as a kind of exception within the criminal offences proper) - do not involve this specific link. Furthermore, even where there is a specific cultural, historical, or ethical 'difference' established, an argument could be made that such (factual) considerations should not always necessarily be followed without a good reason. For instance, certain cultural practices, such as female circumcision, do not fit into the European normative and cultural framework and are therefore legitimately not endorsed by law, regardless of the fact that some countries, communities, or religions in Europe may recognise it as part of their cultural or religious practice.

To sum up the issue, then, trust is culturally calibrated, but so are the fundamental values of a national constitutional and criminal system. While mutual trust had been assumed when the principle of mutual recognition was legally construed and put in place, the subsequent research has shown that in reality very little trust actually existed, which is why many mutual trust-based legal mechanisms work poorly (Vermeulen 2014). Accordingly, the EU is now trying to improve the situation by making policy aimed at increasing trust among and between Member States. One way that this could be achieved is through the formulation of certain standards of effective justice that would apply across the EU (Peršak 2014). Before this could happen, however, an overview of the existing performance of national judiciaries was needed, and this is where the EU has been making significant progress in the last few years, issuing the EU Justice Scoreboard - a tool that assesses the effective functioning of the courts in all Member States - and thereby laying the groundwork for the EU's work on the rule of law.

\footnotetext{
12 The preamble to the Charter of Fundamental Rights of the EU, for example, refers to the values of human dignity, freedom, equality, and solidarity. The preamble of TEU confirms Member States' commitment to the principle of liberty, democracy, respect for human rights, and fundamental freedoms, as well as their commitment to the rule of law and fundamental social rights. Art. 2 of TEU stipulates that the Union is founded on the values of respect for human dignity, freedom, democracy, equality, the rule of law, and respect for human rights, including the rights of persons belonging to minorities. It further claims that these values are common to the Member States in a society in which pluralism, non-discrimination, tolerance, justice, solidarity, and equality between women and men prevail. The $\mathrm{EU}$ is in this way based (or can least claims to be based) on certain common values among all member states.
} 


\section{Rule of law and the EU}

As mentioned above, the rule of law is firmly embedded in the EU's primary legislation. The preamble and Art. 2 of the Treaty on European Union refer to it explicitly as one of the values upon which the EU is built. The EU policy makers have realised, however, that there is a link between the rule of law and trust, and in many recent documents they have specifically recognised the trust-building capacities of adherence to the rule of law.

Accordingly, the EU Justice Agenda for 2020 focuses on the challenges of strengthening "trust, mobility and growth" within the Union, and sets out [385] political priorities in order to achieve this. In light of the challenges that the principle of mutual recognition poses to judicial cooperation, it has also been emphasised that we need to trust judicial decisions fully, no matter where they have been taken, and that this "requires independence, quality and efficiency of the judicial systems and the respect [for] the rule of law" (European Commission 2014a: 4). Regarding the former, the document specifically refers to the EU Justice Scoreboard that has been published annually since 2013 (produced by DG Justice unit "General justice policies and judicial systems"), which provides objective and comparable data on the effectiveness of the functioning of national justice systems in all Member States, where 'effectiveness' is used as an umbrella term for the three main parameters of an effective justice system (i.e. a system that ensures the effective implementation of rights and freedoms) - namely, independence, quality, and efficiency (European Commission 2013; Peršak and Štrus 2014).

On the same day, 11 March 2014, the European Commission released another document, "A new EU Framework to strengthen the Rule of Law" (hereafter: Rule of Law Framework), describing why the rule of law is of fundamental importance for the EU, why this new Framework is needed, how it would work, what would trigger it, and how exactly it will be carried out. The document begins by stating that the rule of law is "the backbone of any modern constitutional democracy", that it is one of the EU's "founding principles, stemming from the common constitutional traditions" of all Member States, that it is one of the EU's "main values", a "precondition for EU membership",13 and that, along with democracy and human rights, it is "one of the three pillars of the Council of Europe" (European Commission 2014b: 2).

But what exactly is meant by rule of law in the EU context? In 2013, Vice-President and Commissioner Reding described it broadly as referring to a system where laws (including the spirit of the law and fundamental rights) are applied and enforced, as well as referring to equality before the law, fairness and due process, prohibition to retrospective changing of laws,

13 The political conditions of the so-called 'Copenhagen criteria' include: stability of institutions guaranteeing democracy, the rule of law, human rights, and respect for and protection of minorities. 
having an independent and impartial judiciary, and being "ultimately a system where justice is not only done, but it is seen to be done, so that the system can be trusted by all citizens to deliver justice" (Reding 2013). The Rule of Law Framework recognises that the precise content of the rule of law standards and principles may vary among Member States, but it also asserts that some principles can be distinguished as the core meaning of the rule of law, and that those are: "legality, [386] which implies a transparent, accountable, democratic and pluralistic process for enacting laws; legal certainty; prohibition of arbitrariness of the executive power; independent and impartial courts; effective judicial review including respect for fundamental rights; and equality before the law" (European Commission 2014b: 4).

Until the Rule of Law Framework was adopted, the EU could only respond to serious threats to the rule of law by activating the mechanisms of Art. 7 TEU. The latter, however, required a "clear risk of a serious breach" (for the preventive mechanisms of Art. 7(1)) or a "serious and persistent breach by a Member State" (for the sanctioning mechanisms of Art. 7(1)). Situations of concern that did not fulfil these conditions, however, would not be considered as a breach of obligation under the Treaties, meaning it remained unclear how the Commission would be able to act, despite recognising a systemic ${ }^{14}$ threat to the rule of law. This Framework was therefore adopted in order to clarify the power of the Commission to address such situations, activating a three-step procedure to be adopted before a situation might escalate and lead to the procedure under Art. 7 TEU. This pre-Article 7 procedure includes: (i) the Commission's assessment of the situation, (ii) the Commission's recommendation on swift and concrete actions, which could be taken to address the systemic threat and avoid the use of Art. 7, and (iii) a follow-up recommendation. The Commission intends to seek a solution through dialogue with the Member State in question, respecting the principle of equal treatment. The European Commission may also seek external expertise, including the input from the EU Agency for Fundamental Rights, as well as advice and assistance from members of the judicial networks in the EU, the Council of Europe, and its Venice Commission.

The Commission's assessment and recommendations are therefore to be based on the results of the dialogue held with the Member State concerned, as well as on any additional material gathered (which the Member State is also entitled to see and be heard on). The assessment, for its part, is to be based on the indications received from available sources and recognised institutions (the Framework specifically mentions the bodies of the Council of Europe and the EU Agency for Fundamental Rights). The recommendation issued, moreover, should indicate reasons for the Commission's concerns, providing specific suggestions on ways to correct the situation and on when this is appropriate, while also recommending that the 14 The threats, however, have to be of a systemic nature. Individual breaches of fundamental rights are still left to be
addressed by the national courts and European Court of Human Rights. 
Member State resolve the issue [387] within a fixed time and informing the Commission of the state that the Member State has taken to address the situation in question (European Commission 2014b).

\section{Conclusion}

In the past and current transitions of SEE societies and their full-blown embracing of the rule of law ideal, the law itself has obviously played a crucial role. Some might see the law as peripheral in comparison with the economy or market forces, yet, inspecting its mediating and transformative role in the post-1989 transitions, as well as in responding to today's global financial crisis, one could hardly agree. In the wake of global financial crisis, laws are being changed, regulation of financial markets is becoming more stringent, and laws on corruption and fraud are being refined, as are professional norms of ethics. In this sense, the law is reactive. However, it is also proactive, actively involved in the shaping of the individual's and a population's morality through normative integration, shaping collective ethics, formulating normative standards of business conduct, and legitimising and delegitimising (especially through criminal law) certain conduct or practices. The fact that the rule of law - its definitional fuzziness notwithstanding - is so often invoked by the man on the street attests to its moral, and not just legal, dimension.

While law can help by shaping the collective ethos, contributing to normative integration and delegitimising certain worrisome social, cultural, political, and economic developments, it cannot do all the work. Social representations and people's attitudes have to change as well. Based on the idea of the trust-belonging-legitimacy-effectiveness nexus (indicated above), one of the ways for the 2004- and 2007-accession countries to move ahead would be to start seeing EU law not as 'foreign law' but as 'our' norms. EU law may have been external law when these countries were not members, but now, as Member States with their own representatives in all EU institutions, they co-shape the law. This way of seeing things would help these states with their sense of 'belonging', and it could help (at least partly) generate trust towards the EU and foster an acceptance of its norms.

The future of the rule of law in Europe (or in SEE, in particular) is impossible to predict. Considering the old adage that power corrupts, the powerful will always be tempted to usurp important state institutions (including the judiciary) to serve their interests, which suggests a certain continuity in the challenges facing the rule of law, stimulated by power struggles as well as cultural [388] diversity and economic fluctuations in Europe. Nevertheless, the progressive engagement of the EU in this area can provide some reassurance that countries (particularly 
their governments) will be scrutinised in case they weaken the rule of law safeguards. Not only are national and international institutions (particularly national courts and the European Court of Human Rights) supervising the state of the rule of law within the countries, from now on the EU (European Commission) oversees it too, thus providing a sort of double safety net, ensuring that national challenges to the rule of law will not be left unchallenged.

\section{References}

Belovič, M. 2014. “Potret tedna: Luka Mesec - novi obraz nove levice," Delo, Sobotna priloga, July 19, 2014, http://www.delo.si/zgodbe/sobotnapriloga/portret-tedna-luka-mesec-noviobraz-nove-levice.html (accessed on 19 July 2014).

Botero, J.C., Nelson, R.L. and C. Pratt. 2011. "Indices and indicators of justice, governance, and the rule of law: An overview," Hague Journal on the Rule of Law 3: 153-169. $<$ doi:10.1017/S1876404511200010> (accessed on 15 July 2014).

Burlyuk, 0. 2013. European Union Rule of Law Promotion in Ukraine: Exploring the Effects of Interaction Between the Institutional Contexts (doctoral dissertation) (Brussels: Brussels School of International Studies of The Department of Politics and International Relations in The Faculty of Social Sciences of The University of Kent).

Bučar, B. 2004. "Independence and integration into the international community: A window of opportunity," in M. Mrak, M. Rojec and C. Silva-Jauregui (eds.), Slovenia: From Yugoslavia to the European Union (Washington: The World Bank): 32-52.

Castles, S. and A. Davidson. 2000. Citizenship and Migration: Globalization and the Politics of Belonging (Basingstoke: Macmillan Press).

Crawford, A. 2000. "Situational crime prevention, urban governance and trust relations," in A. von Hirsch, D. Garland and A. Wakefield (eds.), Ethical and Social Perspectives on Situational Crime Prevention (Oxford: Hart Publishing): 193-215.

Deflem, M. 2008. Sociology of Law: Visions of a Scholarly Tradition (Cambridge, New York: Cambridge University Press).

Dobovšek, B. 2012. "Rule of law versus financial crime," in M. Edelbacher, P.C. Kratcoski and M. Theil (eds.), Financial Crimes: A Threat to Global Security (Boca Raton: CRC Press): 161176.

Elholm, T. 2014. "Legitimacy and EU criminal law regulation," in: N. Peršak (ed.), Legitimacy and Trust in Criminal Law, Policy and Justice: Norms, Procedures, Outcomes (Farnham, Burlington: Ashgate): 71-86. [389] 
Erbežnik, A. 2014. "Mutual Recognition in EU Criminal Law and Its Effects on the Role of a National Judge," in N. Peršak (ed.), Legitimacy and Trust in Criminal Law, Policy and Justice: Norms, Procedures, Outcomes (Farnham, Burlington: Ashgate): 131-151.

Eurobarometer. 2013. Flash Eurobarometer 385: Justice in the EU, Nov. 2013, $<$ http://ec.europa.eu/public_opinion/flash/fl_385_en.pdf> (accessed on 14 September 2014).

_.. 2014. Standard Eurobarometer 81: Public Opinion in the European Union (Spring 2014). http://ec.europa.eu/public_opinion/archives/eb/eb81/eb81_publ_en.pdf (accessed on 30 October 2014).

European Commission. 2012a. Report from the Commission to the European Parliament and the Council on Progress in Romania under the Cooperation and Verification Mechanism, $\begin{array}{lllll}\operatorname{COM}(2012) & 410 & \text { final, July 2012, }\end{array}$ <http://ec.europa.eu/cvm/docs/com_2012_410_en.pdf> (accessed on 15 December 2012).

__. 2012b. Court of Justice rules Hungarian forced early retirement of judges incompatible with EU law, Press release, 6 November 2012, <http://europa.eu/rapid/pressrelease_MEM0-12-832_en.htm> (accessed on 5 May 2013).

_.. 2013. Communication from the Commission to the European Parliament, the Council, the European Central Bank, the European Economic and Social Committee and the Committee of the Regions - The EU Justice Scoreboard: a tool for effective justice and growth, $\operatorname{COM}(2013) 160$ final, 27 March 2013, <http://ec.europa.eu/justice/effectivejustice/files/justice_scoreboard_communication_en.pdf> (accessed on 5 May 2013).

_.. 2014a. Communication from the Commission to the European Parliament, the Council, the European Economic and Social Committee and the Committee of the Regions: The EU Justice Agenda for 2020 - Strengthening Trust, Mobility and Growth within the Union, $\operatorname{COM}(2014) 144$ final, 11 March 2014.

_.. 2014b. Communication from the Commission to the European Parliament and the Council: A new EU Framework to strengthen the Rule of Law, COM(2014) 158 final, 11 March 2014.

Finnis, J. 1980. Natural Law and Natural Rights (Oxford: Oxford University Press).

Flores, I.B. and K.E. Himma. 2013. "Introduction," in I.B. Flores and K.E. Himma (eds.), Law, Liberty, and the Rule of Law (Dordrecht, Heidelberg, New York, London: Springer): 1-10.

Goodall, K., Malloch, M. and B. Munro. 2012. "Social and legal transitions and criminalisation," in K. Goodall, M. Malloch and B. Munro (eds.), Building Justice in Post-Transition Europe? Processes of criminalisation within Central and Eastern European societies (London: Routledge): 3-21. 
Gosztonyi, G. 2005. "Crime as the Cost of Transition - A Social Policy Perspective: The Blind Hole of the European Union," in Z. Kanduč (ed.), Kriminaliteta, družbeno nadzorstvo in postmodernizacijski procesi (Ljubljana: Inštitut za kriminologijo pri Pravni fakulteti v Ljubljani): 263-276. [390]

Harteveld, E., van der Meer, T., and C. E. De Vries. 2013. "In Europe we trust? Exploring three logics of trust in the European Union," European Union Politics 14(4): 542-565.

Jovanović, M.N. 2013. “Was European integration nice while it lasted?" Journal of European Integration 28(1): 1-36.

Jovanović, M.N. and J. Damnjanović. 2013. "EU Eastern Enlargement: Economic Effects on New Members 2000 2012," Journal of Economic Integration 29(2): 201-243.

Kanduč, Z. 2013. Politika, pravo, ekonomija in kriminal: kriminološke refleksije postomoderne družbe in culture (Ljubljana: Inštitut za kriminologijo).

Kotar. T. 2009. "Slovenia," in L. Stan (ed.), Transitional Justice in Eastern Europe and the Former Soviet Union: Reckoning with the Communist Past: 1 (New York: Routledge): 200-220.

Letki, N. and G. Evans. 2005. "Endogenizing social trust: Democratization in East-Central Europe," British Journal of Political Science 35(3): 515-529.

Mishler, W. and Rose, R. 1997. "Trust, distrust and scepticism: Popular evaluations of civil and political institutions in post-Communist societies," The Journal of Politics, 59(2): 418-51.

Nardulli, P. F., Peyton, B. and J. Bajjalieh. 2013. "Conceptualizing and Measuring Rule of Law Constructs, 1850-2010," Journal of Law and Courts 1(1): 139-192.

Nuotio, K. 2014. "Between denial and recognition: Criminal law and cultural diversity," in W. Kymlicka, C. Lernestedt and M. Matravers (eds.), Criminal Law and Cultural Diversity (Oxford: Oxford University Press): 15-46.

Peršak, N. 2007. Criminalising Harmful Conduct: The Harm Principle, its Limits and Continental Counterparts (New York: Springer).

__. 2011. "Managing insecurities and expectations: Social trust and judiciary in transition," Shaken Order: Authority and Social Trust in Post-Communist Societies (Case studies in Law) - CAS Working Paper Series 4: 3-33.

_.. 2012. "Building justice through criminal law: issues of criminalisation and trust," in K. Goodall, M. Malloch and B. Munro (eds.), Building Justice in Post-Transition Europe? Processes of Criminalisation within Central and Eastern European Societies (London: Routledge): 43-55.

__. 2014. "Shared standards of justice: towards normative indicators of judicial legitimacy at EU level," in L. Pauwels and G. Vermeulen (eds.), Update in de criminologie VII: Actuele ontwikkelingen inzake EU-justitiebeleid, cannabisbeleid, misdaad en straf, jongeren en 
jeugdzorg, internationale vrede, veiligheid en gerechtigheid, gewelddadig extremisme \& private veiligheid en zelfregulering (Antwerpen, Apeldoorn, Portland: Maklu): 45-65.

Peršak, N., and J. Štrus. 2014. "Legitimacy and trust-related issues of judiciary: New challenges for Europe," in N. Peršak (ed.), Legitimacy and Trust in Criminal Law, Policy and Justice (Farnham, Burlington: Ashgate): 89-110. [391]

Reding, V. 2012. Speech at the European Parliament. 12 September 2012, <http://www.europarl.europa.eu/ep-live/en/plenary/video?debate=1347455074438> (accessed on 9 December 2012).

_.. 2013. "The EU and the Rule of Law - What next?" (press release). <http://europa.eu/rapid/press-release_SPEECH-13-677_en.htm> (accessed on 20 October 2014).

Rose-Ackerman, S. 2001. "Trust and Honesty in Post-Socialist Societies," Kyklos 54(2/3): 415444.

Slavov, A. 2011. "Challenges to constitutional supremacy in a new democracy: A critical study of Bulgaria," Shaken Order: Authority and Social Trust in Post-Communist Societies (Case studies in Law) - CAS Working Paper Series 4: 3-30.

Stoeckel, F. 2012. "Ambivalent or indifferent? Reconsidering the structure of EU public opinion," European Union Politics 14(1): 23-45.

Tamanaha, B.Z. 2004. On the Rule of Law (Cambridge: Cambridge University Press).

Taylor Hamara, C. 2013. "The concept of the rule of law," in I.B. Flores and K.E. Himma (eds.), Law, Liberty, and the Rule of Law (Dordrecht, Heidelberg, New York, London: Springer): $11-26$.

Toshkov, D., Kortenska, E., Dimitrova, A., and A. Fagan. 2014. "The 'old' and the 'new' Europeans: Analyses of public opinion on EU enlargement in review," in MAXCAP Working Paper Series 2, April 2014.

Tyler, T. R. 2003. "Procedural justice, legitimacy, and the effective rule of law," Crime and Justice: A Review of Research 30: 283-357.

__. 2009. "Legitimacy and compliance: The benefits of self-regulation," Ohio State Journal of Criminal Law 7(1): 307-359.

__. (ed.). 2012. Legitimacy and Criminal Justice: International Perspectives (New York: Russell Sage Foundation).

Vermeulen, G. 2014. "Flaws and contradictions in the mutual trust and recognition discourse: Casting a shadow on the legitimacy of EU criminal policy making and judicial cooperation in criminal matters?" in N. Peršak (ed.), Legitimacy and Trust in Criminal Law, Policy and Justice: Norms, Procedures, Outcomes (Farnham, Burlington: Ashgate): 153-175. 
Waldron, J. 2002. "Is the rule of law an essentially contested concept (in Florida)?" Law and Philosophy 21: 137-164.

_.. 2008. "The concept and the rule of law," NYU Public Law \& Legal Theory Research Paper Series, Working Paper no. 08-50: 1-67.

Wolff, S. 2013. "The rule of law in the Area of freedom, security and justice: Monitoring at home what the European Union preaches abroad," Hague Journal on the Rule of Law 5: 119131. 